\title{
Antarctotrechus balli sp. n. (Carabidae, Trechini): the first ground beetle from Antarctica
}

\author{
Allan C. Ashworth', Terry L. Erwin ${ }^{2}$ \\ I Quaternary Entomology Lab, Department of Geosciences, North Dakota State University, Fargo, North \\ Dakota 58108, USA 2 Hyper-diversity Group, Department of Entomology, MRC-187, National Museum of \\ Natural History, Smithsonian Institution, Washington, P.O. Box 37012, DC 20013-7012, USA
}

Corresponding author: Allan C. Ashworth (allan.ashworth@ndsu.edu)

Academic editor: L. Penev | Received 16 September 2016 | Accepted 28 October 2016 | Published 23 November 2016

http://zoobank.org/9B1AF440-DC5B-4137-9646-1ED8B28140F0

Citation: Ashworth AC, Erwin TL (2016) Antarctotrechus balli sp. n. (Carabidae, Trechini): the first ground beetle from Antarctica. ZooKeys 635: 109-122. doi: 10.3897/zookeys.635.10535

\begin{abstract}
Fossil elytra of a small trechine carabid are reported from the Oliver Bluffs on the Beardmore Glacier at lat. $85^{\circ} \mathrm{S}$. They were compared with counterparts from the extant genera Trechisibus, Tasmanorites, Oxytrechus and Pseudocnides. The fossils share some characters but are sufficiently different to be described as a new genus and species. We named the new species Antarctotrechus balli in honour of George E. Ball who made major contributions to the study of carabids through his own research and the training of students while at the University of Alberta, Edmonton, Alberta, Canada. The closest extant relatives to the extinct $A$. balli are species of Trechisibus, which inhabit South America, the Falkland Islands and South Georgia, and Tasmanorites, which inhabit Tasmania, Australia. Plant fossils associated with A. balli included Nothofagus (southern beech), Ranunculus (buttercup), moss mats and cushion plants that were part of a tundra biome. Collectively, the stratigraphic relationships and the growth characteristics of the fossil plants indicate that $A$. balli inhabited the sparsely-vegetated banks of a stream that was part of an outwash plain at the head of a fjord in the Transantarctic Mountains. Other insects represented by fossils in the tundra biome include a listroderine weevil and a cyclorrhaphan fly. The age of the fossils, based on comparison of associated pollen with ${ }^{40} \mathrm{Ar} /{ }^{39} \mathrm{Ar}$ dated pollen assemblages from the McMurdo Dry Valleys, is probably Early to Mid-Miocene in the range 14-20 Ma. The tundra biome, including $A$. balli, became extinct in the interior of Antarctica about $14 \mathrm{Ma}$ and on the margins of the continent by 10-13 Ma. A. balli confirms that trechines were once widely distributed in Gondwana. For $A$. balli and other elements of the tundra biome it appears they continued to inhabit a warmer Antarctica for many millions of years after rifting of Tasmania (45 Ma) and southern South America (31 Ma).
\end{abstract}

Copyright Allan C.Ashworth, Terry L. Erwin. This is an open access article distributed under the terms of the Creative Commons Attribution License (CC BY 4.0), which permits unrestricted use, distribution, and reproduction in any medium, provided the original author and source are credited. 


\section{Keywords}

Trechini, Carabidae, Antarctica, Miocene

\section{Introduction}

Insects are least well-represented in Antarctica than anywhere else on Earth. The living fauna consists of three species of flightless chironomid midges. Two of these are considered native and one is adventive. Molecular analysis confirms that $B$. antarctica and Eretmoptera murphyi Schaeffer are closely related in the subfamily Orthocladiinae and represent an ancient Antarctic lineage. Parochlus steinenii (Gerke), the third species, is in the subfamily Podonominae and more closely related to an older lineage from Tierra del Fuego and South Georgia (Allegruchi et al. 2006). Both of the native species occur on the west side of the Antarctic Peninsula and offshore islands, and also South Shetland, South Orkney and the South Sandwich Islands (Convey and Block 1996). Only one of them, Belgica antarctica Jacobs, 1900, is truly restricted to the Antarctica Peninsula and subantarctic islands. The lack of available moisture, low temperatures and vegetation are considered limiting factors. The furthest south $B$. antarctica is known from is $68^{\circ} \mathrm{S}$ (Convey and Block 1996).

The fossil record for insects in Antarctica is equally poor. Older records are reviewed by Carpenter (1969). Impressions of wings and distorted bodies in late Paleozoic to middle Mesozoic-aged carbonaceous shales have proved difficult to assign to anything other than the broadest categories e.g. Odonata, Homoptera and Coleoptera. Newer records for insects are from Neogene-aged deposits in the Transantarctic Mountains. They differ from the older insects in that they are pieces of exoskeletal elements, not impressions. A fragment of an elytron, possibly a curculionid, was reported from 14 million year old deposits in the Olympus Range in the McMurdo Dry Valleys (Lewis et al. 2008). Exceptionally well-preserved beetle fragments, including a pronotum covered in fine setae, were reported from a soil profile in the New Mountain area, also in the McMurdo Dry Valleys (Mahaney et al. 2012). The specimens were said to be of Miocene age but because of the preservation of the fine setae we do not accept that the specimens are fossil. Most probably they represent parts of a modern beetle that had contaminated the sample in storage in North America before analysis.

The fossil trechine we report is from the same stratigraphic horizon as a head and a leg of a listroderine weevil (Ashworth and Kuschel 2003) and the posterior segments of a puparium of a cyclorraphan fly (Ashworth and Thompson 2003)

\section{Location and stratigraphy of the Meyer Desert Formation}

The fossils come from the Oliver Bluffs on the Beardmore Glacier which is a major outlet glacier of the East Antarctic Ice Sheet. The site is within the Transantarctic 


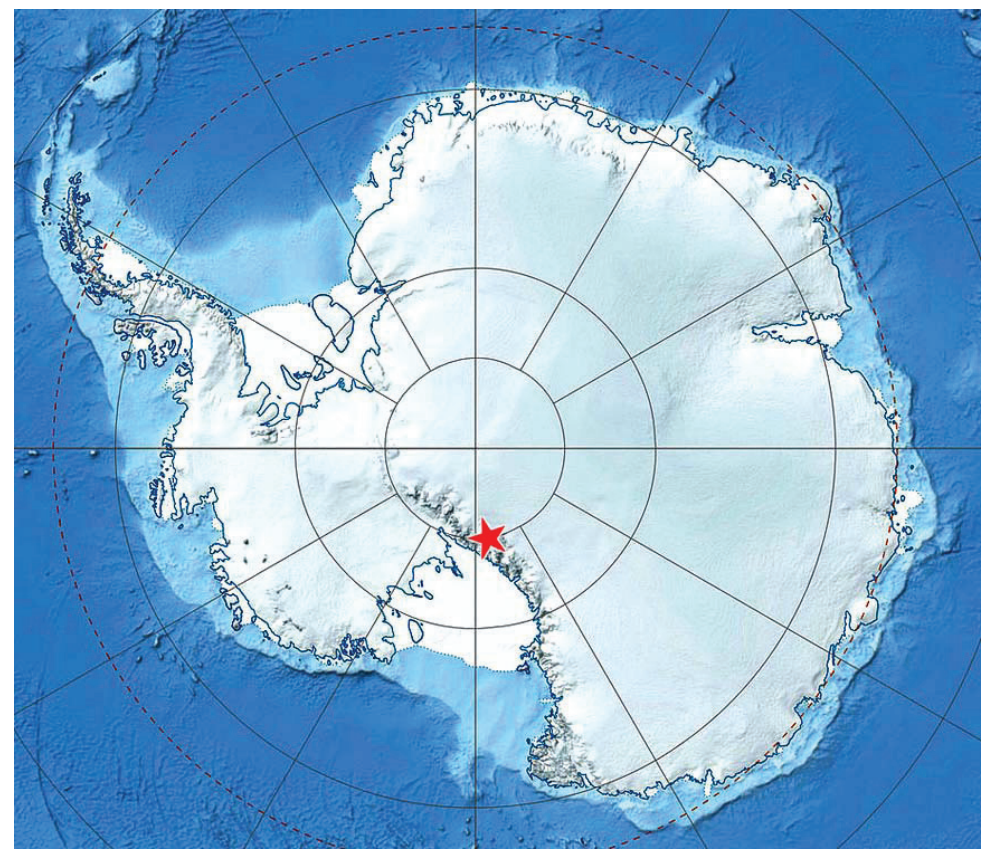

Figure I. The type locality for Antarctotrechus balli sp. $\mathrm{n}$. is shown by the red star. Image map is a modified MODIS Mosaic of Antarctica from National Snow and Ice Data Center, http://nsidc.org/data/moa/

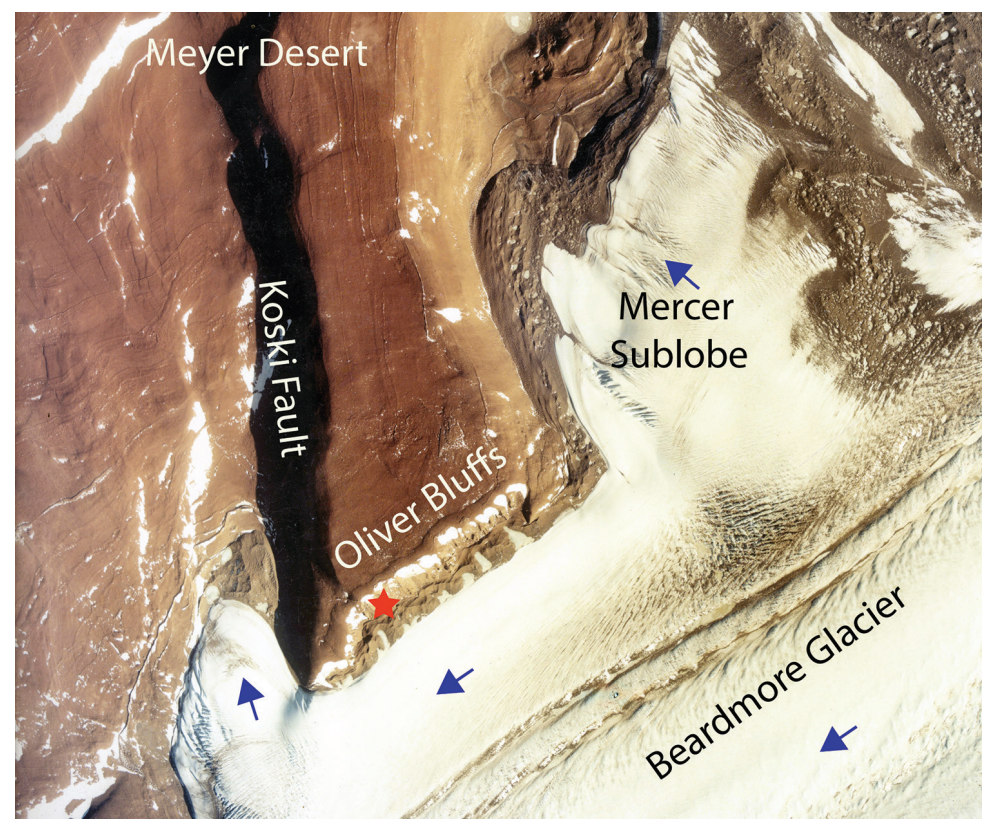

Figure 2. An aerial view of the Oliver Bluffs on the Beardmore Glacier. Ice flow directions are shown by the blue arrows. The Meyer Desert Formation is downthrown to the north along the Koski Fault. The type locality for A.balli sp. n. is shown by a red star. The aerial image \# TMA-2738-4 is from the collections of the The United States Antarctic Resource Center (USARC), USGS, Reston, VA. 


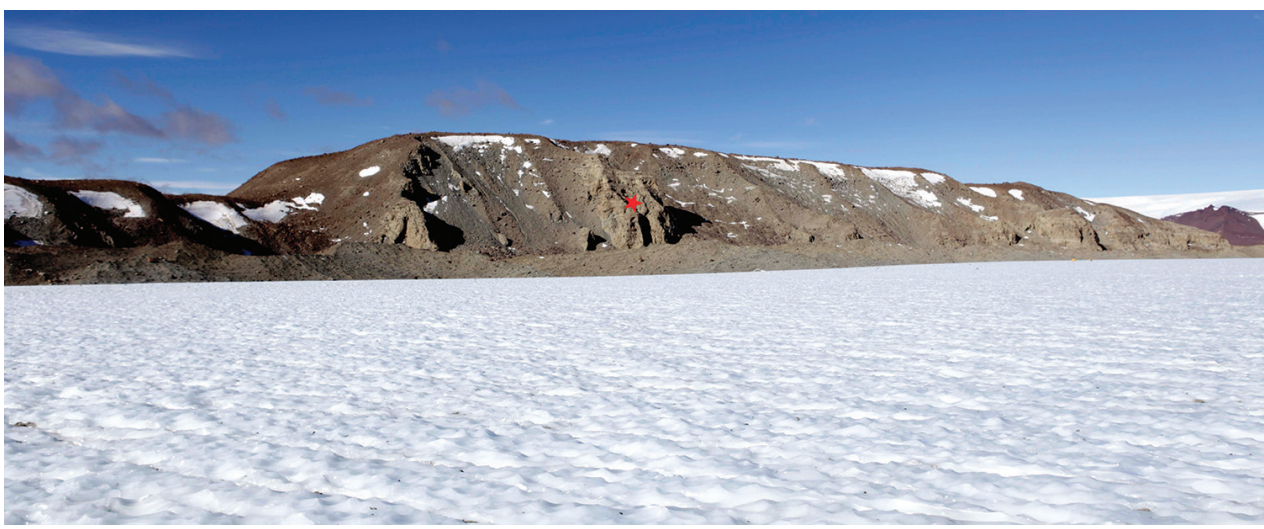

Figure 3. Ancient glacial deposits of the Meyer Desert Formation exposed in the Oliver Bluffs on the flanks of the Beardmore Glacier. The deposits are downthrown along the Koski fault which is marked by the prominent escarpment towards the north end of the bluffs (left on image). The type locality for $A$. balli sp. $n$. is at the north end of the bluffs marked by a red star.

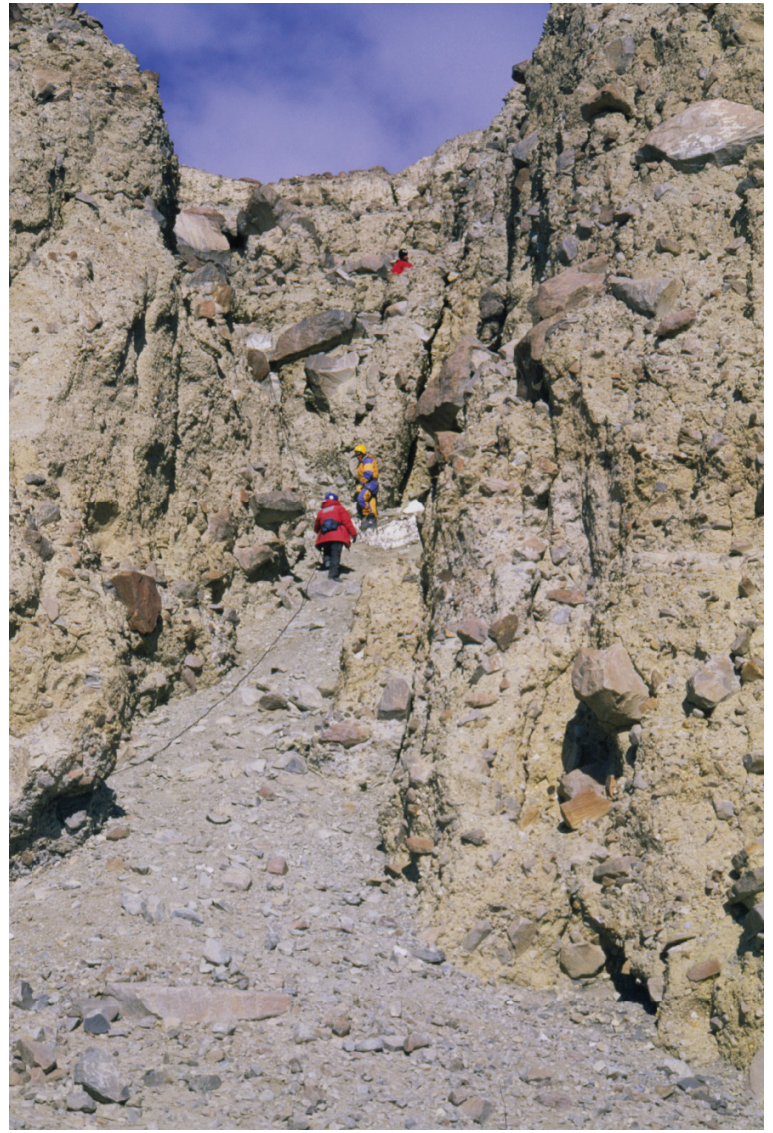

Figure 4. The type locality for $A$. balli sp. n. is a siltstone lens within a sequence of lodgement tills exposed in the gulley wall to the left of the person highest in the gully. 
Mountains about $550 \mathrm{~km}$ from the South Pole (Figure1). As uplift occurred on the flanks of the Ross Sea rift, the Beardmore Glacier became progressively entrenched leaving older glacial deposits on the flanks (Figures 2-4). The present elevation of the Oliver Bluffs is $1731 \mathrm{~m}$ above msl. However, based on a report of agglutinated foraminifera from the basal deposits at the Oliver Bluffs (Webb et al. 1994), it is probable that the deposits in which Antarctotrechus balli and other fossils were preserved accumulated near sea-level on the margins of a fjord. The older glaciogene deposits of the Beardmore Glacier region are referred to as the Mt. Mills, Meyer Desert and Cloudmaker Formations of the Sirius Group, formerly Sirius Formation (McKelvey et al. 1991; Webb et al. 1996). The Meyer Desert Formation is the youngest of these and the only one known to contain in situ fossils from terrestrial and freshwater habitats. The trechine fossils come from a siltstone lens located about $20 \mathrm{~m}$ above the base of a bluff located at $85.117222^{\circ} \mathrm{S}, 166.657500^{\circ} \mathrm{E}$ (Figures 2-4).

The lens is interbedded within large boulder diamictites and is part of a horizon containing outwash sandstones and conglomerates, laminated proglacial lake deposits, debris flows, peat beds and shallow lacustrine mudstones. The siltstone lens formed from the infilling of a stream channel. Insect and plant parts were washed or blown into the stream channel which eventually became sediment-choked and finally buried by lodgement till during the next glacial advance down the valley. The Oliver Bluffs stratigraphy supports the interpretation that the stream was part of a broad outwash plain that extended between the glacier margin and the fjord (Ashworth and Cantrill 2004).

\section{Paleoecology}

The Oliver Bluffs on the Beardmore Glacier is one of the most important Neogene terrestrial paleontological sites in Antarctica. The possibility that fossils might be found there was first noted by John Mercer. He recognized that the wet-based glacial sediments exposed in the bluffs could only have been deposited at the time when the climate was warmer and wetter than it is now (Mercer 1972). On a later expedition, fossil wood was discovered (Webb and Harwood 1987) and assigned to Nothofagus (Carlquist, 1987). This was followed by the discovery of a mat of Nothofagus leaves, one-leaf thick. The leaves have similar size and shape to the extant sub-alpine $N$. gunnii from Tasmania. They have a different veination pattern, however, which led to them being described as an extinct species, $N$. beardmoreensis (Hill et al., 1996). An analysis of tree rings of the abundant twig-sized Nothofagus wood indicated prostate shrubs rather than trees (Francis and Hill 1996). Pollen from the site is represented by a single species of Nothofagus, N. lachlaniae (Askin and Markgraf 1986). Other plant fossils from the site, notably abundant achenes of Ranunculus and cushion plants of both moss and an angiosperm species, indicate a patchy shrub tundra (Ashworth and Cantrill 2004). The habitat for the new species of trechine was the sparsely vegetated sand and gravel banks of a meltwater-fed stream. 


\section{Age of the deposits}

Based on the occurrence of marine diatoms within the Sirius Group deposits, their age was reported as Pliocene c. $3 \mathrm{Ma}$ (Webb et al. 1994). This age estimate, however, is controversial and likely too young. Several studies suggest that the diatoms were deposited onto older glacial deposits by wind from Pliocene marine deposits located on the margins of the continent (Scherer et al. 2015). Two lines of evidence from the Oliver Bluffs, one geomorphological and the other palynological, also support an older age for the deposits.

The Meyer Desert Formation at the northern end of the Oliver Bluffs is off-set by splay faults associated with the Koski Fault (Figure 2). Surface exposure ages of Beardmore moraine boulders overlying the Meyer Desert Formation, and offset by faults, are between 1.9-5.8 Ma (Ackert and Kurz 2004). The estimate assumed no erosion and constant elevation leading the authors of the study to conclude that the Meyer Desert Formation had to be much older than c.3 Ma.

Pollen from the Meyer Desert Formation most closely matches an assemblage from near Mount Boreas in the McMurdo Dry Valleys dated by ${ }^{39} \mathrm{Ar} /{ }^{40} \mathrm{Ar}$ from a volcanic ash to be of mid-Miocene age (14.07 $\pm 0.05 \mathrm{Ma}$., Lewis et al. 2008). Also, fossiliferous Neogene deposits in the region of the Friis Hills in the McMurdo Dry Valleys are early to mid-Miocene based on ${ }^{39} \mathrm{Ar} /{ }^{40} \mathrm{Ar}$ dating (Lewis and Ashworth 2016). We conclude that the best age estimate for the trechine fossils is mid-Miocene. Certainly it is possible that the retreat of glaciers and colonization by a tundra biota correlates with the mid-Miocene climatic optimum, a well-known globally warm climatic event (Flower and Kennett 1995, Warny et al. 2009, Feakins et al. 2012).

\section{Fossil preparation}

The fossiliferous siltstone is calcite-cemented which disaggregated after soaking in water. The grains were further separated by washing in a jet of water and those that remained on a $300 \mu$ mesh were then examined under a binocular microscope $(20 \times)$. Fossils picked from the sediment matrix in addition to the trechine elytra included twigs of Nothofagus (southern beech) wood, moss stems, seeds of Ranunculus (buttercups) (Ashworth and Cantrill 2004).

\section{Description}

Antarctotrechus Ashworth \& Erwin, gen. n. http://zoobank.org/698F1D95-6514-4AED-8E6A-F29EBD6C6014

Type species. Antarctotrechus balli Ashworth \& Erwin, sp. n. 

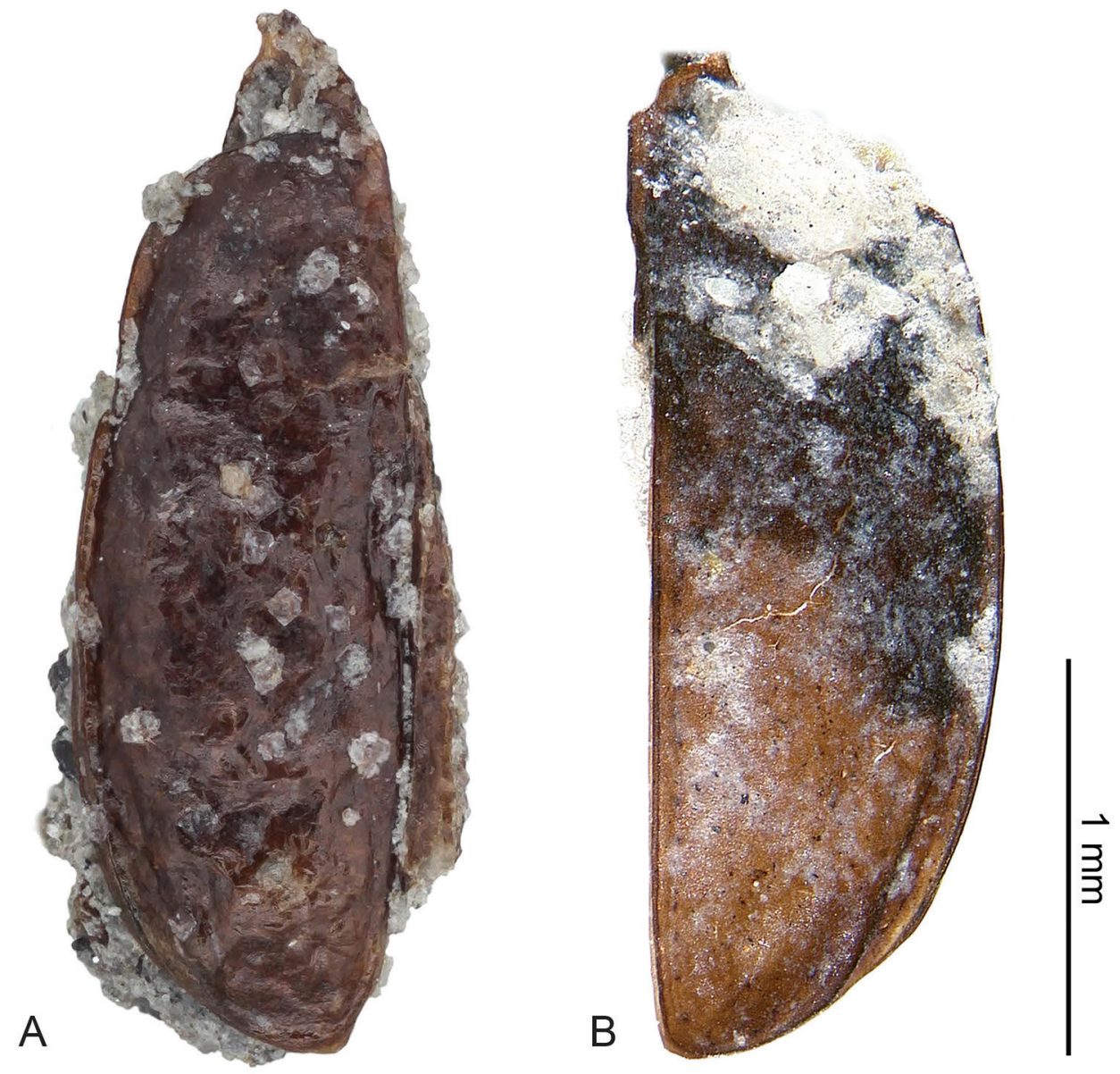

Figure 5. Fossils of the left and right elytra of $A$. balli sp. n. A The left elytron, $2.36 \mathrm{~mm}$ in length, is designated as the paratype (USNM: ADP147732). A small part of the right elytron of the same individual is attached along the suture near the apex. The siltstone matrix is visible along the outer margin near the apex. The small rhomb-shaped crystals on the surface are authigenic calcite $\mathbf{B}$ The right elytron is designated as the holotype. (NMNH: ADP147741). The elytron is $2.40 \mathrm{~mm}$ in length. The base is deformed by a crack and concealed by sediment grains. A small part of the left elytron of the same individual is still attached along the suture near the base.

\section{Antarctotrechus balli Ashworth \& Erwin, sp. n.}

http://zoobank.org/B5A220C2-B707-489D-ACCD-03980BD2A231

Holotype (sex unknown), a right elytron. Antarctica, Oliver Bluffs, Beardmore Glacier region, Meyer Desert Formation, $85.117222^{\circ} \mathrm{S}, 166.657500^{\circ} \mathrm{E}$, (Allan Ashworth 2003) (NMNH: ADP147741).

Derivation of genus name. Antarctotrechus refers to its relationship with the Trechini and the place where the specimens were found. 

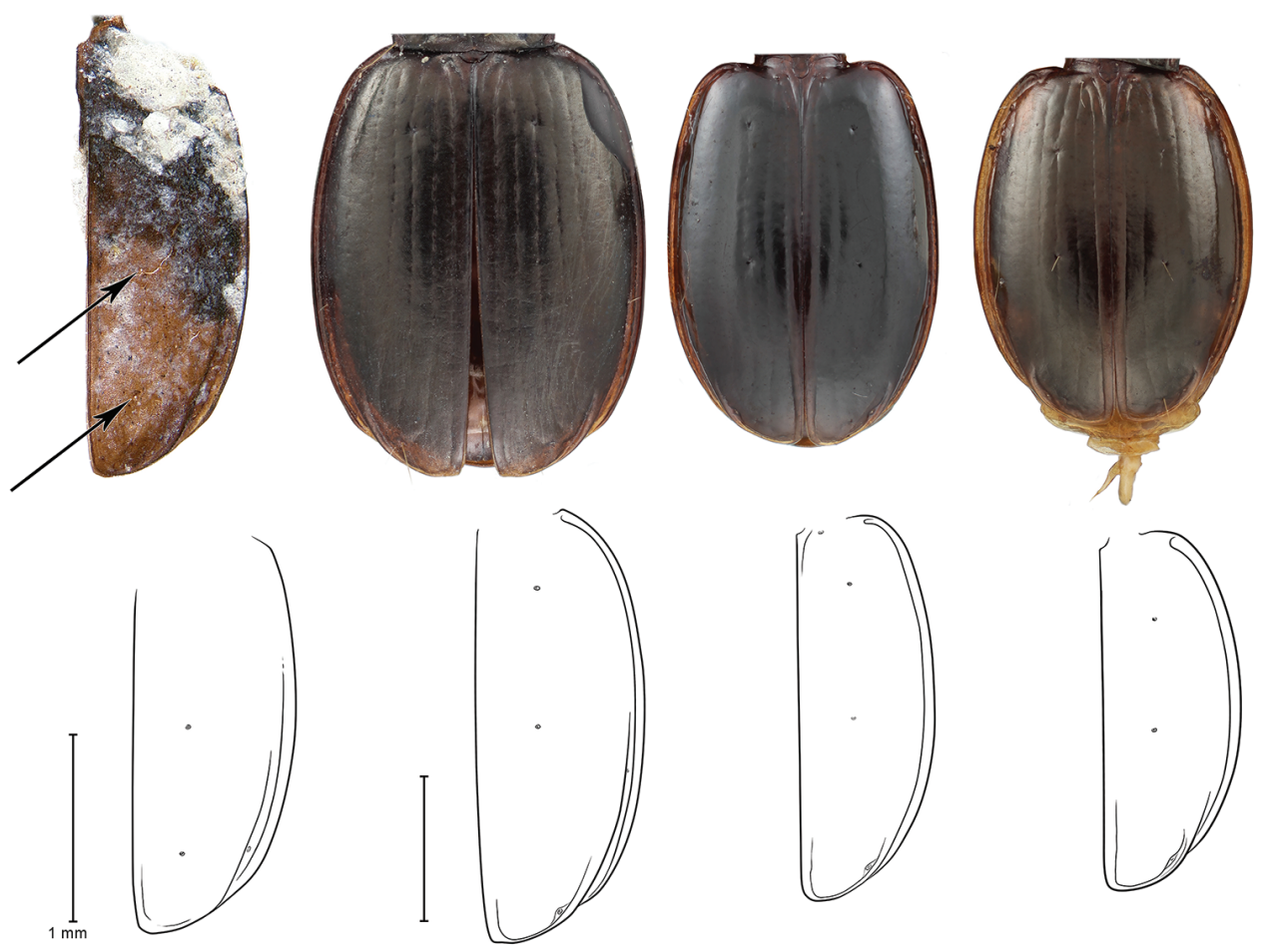

Figure 6. Fossil of right elytron of $A$. balli sp. n. and elytra of three species of Neaustral Trechisibus spp. with line drawings of each showing $3^{\text {rd }}$ interval setigerous pores and recurrent grooves of the latter.

Derivation of specific epithet. The epithet, balli, is a Latinized eponym based on the family name of George E. Ball, Carabidologist, and academic leader of a host of younger carabidologists, in celebration of his $90^{\text {th }}$ birthday, September 26, 2016.

Proposed english vernacular name. Ball's Antarctic Tundra Beetle.

Diagnosis. Only the left and right elytra known (Figure 5). They are from two individuals. Form as in alate Neaustral trechines in the genus Trechisibus Motschulsky 1862. Lack of recurrent groove as in Andean and Pampas trechines in the genera Oxytrechus Jeannel, 1927 and Pseudocnides Jeannel 1927, respectively. Placement of mid-discal elytral setiferous pore as in Trechisibus and other trechines, Placement of preapical in third interneur unique (Figures 6-7). Absence of apical elytral setiferous pore in third interneur unique.

Description. (Figures 5-7). Size: Elytron length and width within range of Trechisibus species, Length $2.36 \mathrm{~mm}, \mathrm{~W}=0.85 \mathrm{~mm}$.

Color: Typically trechine brown.

Luster: Unknown due to deposition and lithification processes over $\sim 20-14 \mathrm{Ma}$.

Microsculpture: Apparently isodiametric.

Head: Unknown.

Prothorax: Unknown. 

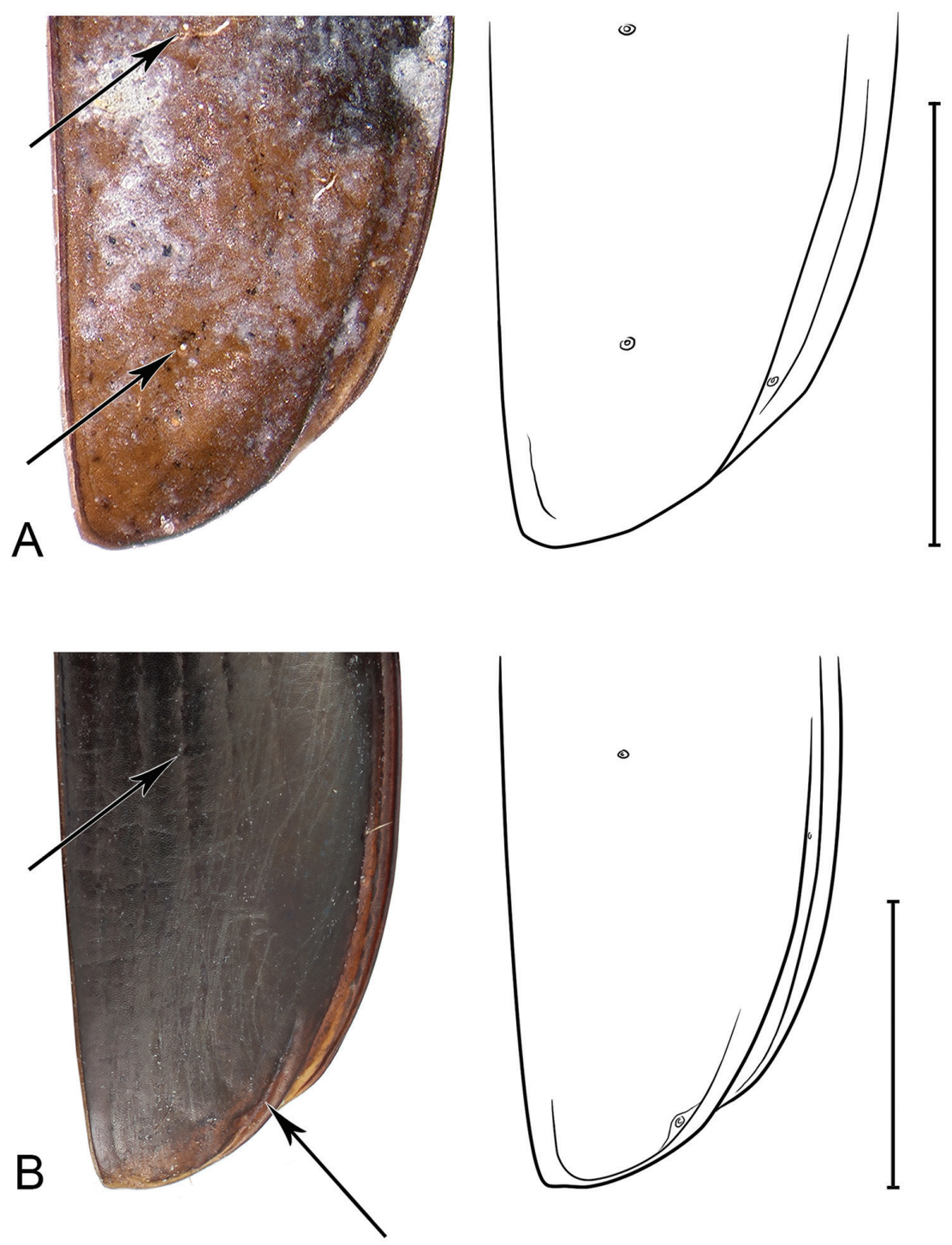

Figure 7. Comparison of the apices of the fossil right elytron A. balli sp. n. and a modern Trechisibus sp. with line drawings of each showing $3^{\text {rd }}$ interval setigerous pores and recurrent grooves of the latter. An isodiametric microornament is partially visible on the fossil.

Pterothorax: Shape of humerus (compare Figure 5) not sloped, indicating the adult was possibly fully winged.

Legs: Unknown.

Abdomen: Unknown.

Male genitalia: Unknown.

Female genitalia: Unknown. 
Dispersal potential. If these beetles were macropterous (see above), they were likely capable of flight. Trechisibus adults are moderately swift and agile runners, so likely were adults of $A$. balli. All known species of Tasmanorites are brachypterous.

Other specimens examined. A left elytron also from the type locality is designated as the paratype. This specimen is reposited in the collections of the Smithsonian Institution National Museum of Natural History (NMNH:ADP147732).

\section{Systematics and biogeographic significance}

Our search for relationships of the fossil species focused on four genera of southern trechines: Trechisibus Motschulsky 1862, Tasmanorites Jeannel 1927, Oxytrechus Jean-

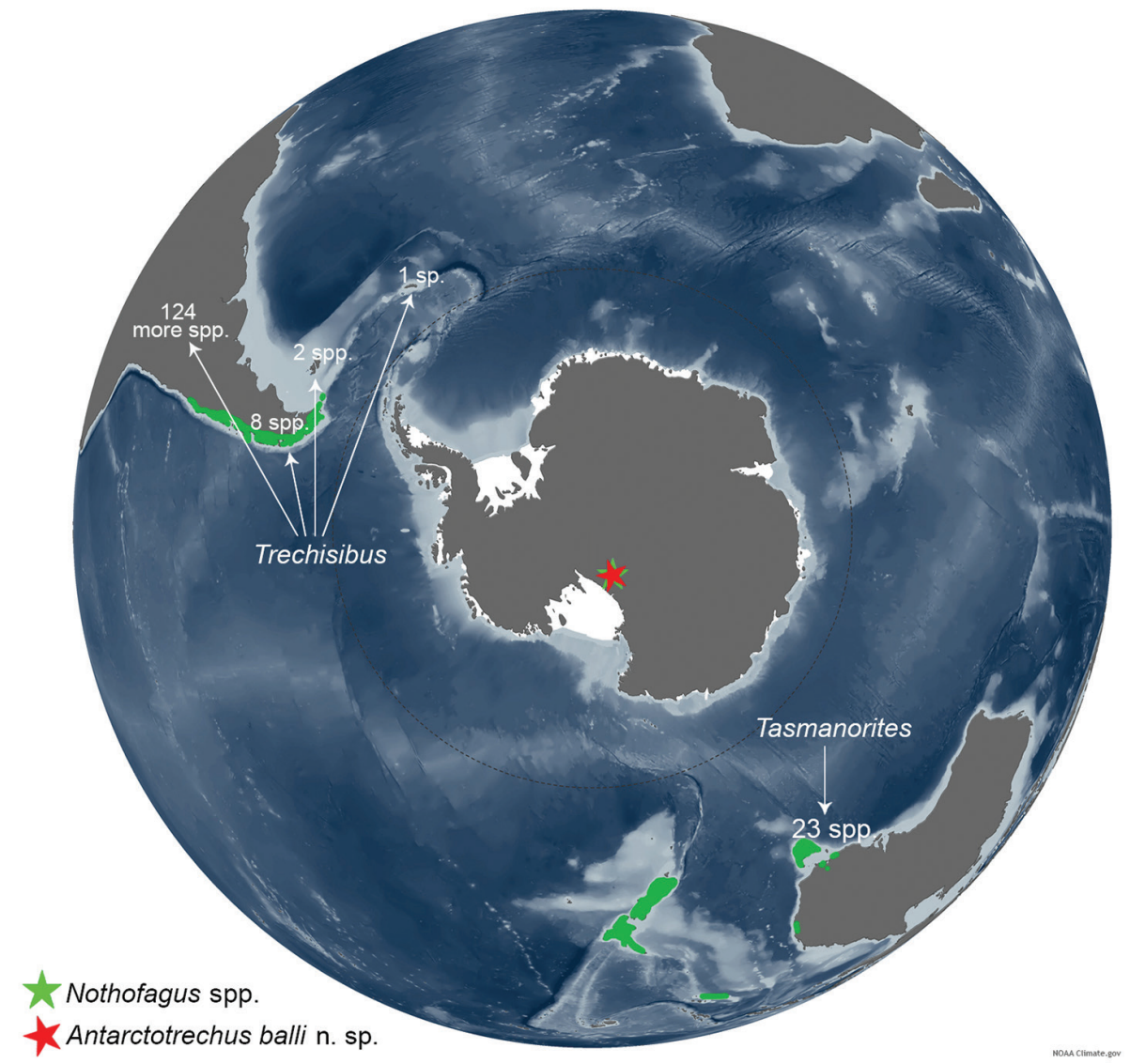

Figure 8. The distribution of extant species of Trechisibus, Tasmanorites and Nothofagus and the fossil occurrence of $A$. balli sp. n. and Nothofagus beardmorensis on the Beardmore Glacier shown by red and green stars: information for Trechisibus species (Allegro et al., 2008) and Tasmanorites (Eberhard S, Giachino, PM, 2011). Base image: NOAA Climate.gov https://www.climate.gov/news-features/understanding-climate/polar-opposites-arctic-and-antarctic 
nel, 1927, and Pseudocnides Jeannel, 1927. Oxytrechus and Pseudocnides share with the fossil a unique feature in trechines, i.e., lack of a recurrent groove, however, neither is associated with Nothofagus (southern beech) forests, rather they are for the most part montane and lowland grassland species (La Puna and La Pampa). In addition, the latter two genera are not truly Neaustral, rather Andean or Pampean.

With the exception of the lack of a recurrent groove, the fossils are similar in size and shape and in the placement of mid-discal elytral setiferous pore to Trechisibus and Tasmanorites. These genera are very closely related (David Maddison, Oregon State University, pers. comm., based on molecular studies). Trechisibus is abundant in the fauna of southernmost South America extending northward to the Andes in Peru and Ecuador. Tasmanorites occurs in Tasmania but not on the mainland of Australia or New Zealand. Trechisibus and Tasmanorites have a circum-Antarctic relationship and both are associated with Nothofagus forests, as was the new genus and species Antarctotrechus balli (Figure 8).

The conflicting signals both in anatomical attributes and biogeography, and in ecological setting as well, leave open the question of relationships, thus giving us no alternative but to flag the species represented by fossil evidence through erection of new genus status, hence drawing attention to it and the need for further paleontological studies in Antarctica.

The type locality of $A$. balli is midway between Tasmania and southernmost Patagonia (4600 vs $4300 \mathrm{~km}$ ) suggesting that Trechisibus-Tasmanorites-like clades occupied a vast area of the southern land masses prior to $\sim 14 \mathrm{Ma}$ ago (Figure 8 ). There is no known Trechisibus-Tasmanorites- like clade in New Zealand where the southernmost part is only 3 degrees further north than the southernmost part of Tasmania. The absence of the clade in New Zealand adds fuel to the controversial hypothesis that the original Gondwana biota of New Zealand was drowned during marine transgression in the Oligocene and/or the early Miocene (Mildenhall et al. 2014).

Populations of Antarctotrechus balli had probably become extinct in the Beardmore Glacier region (lat. $85^{\circ} \mathrm{S}$ ) by $\sim 14 \mathrm{Ma}$ ago, or earlier. Further north in the Olympus Range (lat. $77^{\circ} \mathrm{S}$ ), in the McMurdo Dry Valleys, major climate change at $\sim 14 \mathrm{Ma}$ ago resulted in the extinction of the tundra biota (Lewis et al. 2008). The warmth and moisture needed to support patches of tundra with Nothofagus, and populations of $A$. balli, may have persisted on the margins of the continent (lat. $65^{\circ} \mathrm{S}$ ) until $10-13 \mathrm{Ma}$ ago (Anderson et al. 2011, Wei et al. 2013). Eventually, however, the climate became too cold and too dry to support anything but extremophiles.

\section{Acknowlegements}

We extend hearty thanks to Karolyn Darrow of the Department of Entomology at the Smithsonian Institution for elytron images and outline drawings of adults of extant three species of Trechisibus. We also warmly thank David Maddison for assistance in understanding the southern trechine complexity. ACA acknowledges the logistics sup- 
port of the US Antarctic program for the field study on the Beardmore Glacier and colleagues who assisted in the field study: David Cantrill, Jane Francis, Forrest McCarthy, Marty Reed and Steve Roof. The research was supported by NSF grants 9615252 and 0947821.

\section{References}

Ackert RP, Kurz MD (2004) Age and uplift rates of Sirius Group sediments in the Dominion range, Antarctica, from surface exposure dating and geomorphology. Global and Planetary Change 42(1-4): 207-225. doi: 10.1016/j.gloplacha.2004.02.001

Allegro G, Giachino PM, Sciaky R (2008) Notes on some Trechini (Coleoptera Carabidae) of South America with description of new species from Chile, Ecuador and Peru. Biodiversity of South America, I. Memoirs on Biodiversity 1: 131-171.

Allegrucci G, Carchini G, Todisco V, Convey P, Sbordoni V (2006) A molecular phylogeny of Antarctic chironomidae and its implications for biogeographical history. Polar Biology 29: 320-326. doi: 10.1007/s00300-005-0056-7

Anderson JB, Warny S, Askin RA, Wellner JS, Bohaty SM, Kirshner AE, Livsey DN, Simms AR, Smith TR, Ehrmanng W, Lawver LA, Barbeau D, Wise SW, Kulhanek DK, Weaver FM, Majewski W (2011) Progressive Cenozoic cooling and the demise of Antarctica's last refugium. PNAS 108(28): 11356-11360. doi: 10.1073/pnas.1014885108

Ashworth AC, Cantrill DJ (2004) Neogene vegetation of the Meyer desert formation (Sirius Group) Transantarctic Mountains, Antarctica. Palaeogeography Palaeoclimatology Palaeoecology 213(1-2): 65-82. doi: 10.1016/S0031-0182(04)00359-1

Ashworth AC, Kuschel G (2003) Fossil weevils (Coleoptera : Curculionidae) from latitude 85 degrees S Antarctica. Palaeogeography Palaeoclimatology Palaeoecology 191(2): 191-202. doi: 10.1016/S0031-0182(02)00712-5

Ashworth AC, Thompson FC (2003) A fly in the biogeographic ointment. Nature 423: 135-136. doi: $10.1038 / 423135$ a

Askin RA, Markgraf V (1986) Palynomorphs from the Sirius Formation, Dominion Range, Antarctica. Antarctic Journal of Science 21(5): 34-35.

Carlquist S (1987) Pliocene Nothofagus wood from the Transantarctic Mountains. Aliso 11: $571-583$.

Carpenter F (1969) Fossil insects from Antarctica. Psyche 76: 418-425. doi: 10.1155/1969/17070

Convey P, Block W (1996) Antarctic Diptera: Ecology, physiology and distribution. European Journal of Entomology 93(1): 1-13.

Eberhard S, Giachino PM (2011) Tasmanian Trechinae and Psydrinae (Coleoptera, Carabidae): a taxonomic and biogeographic synthesis, with description of new species and evaluation of the impact of Quaternary climate changes on evolution of the subterranean fauna. Subterranean Biology 9: 1-72. doi: 10.3897/subtbiol.9.2516

Feakins SJ, Warny S, Lee J-E (2012) Hydrologic cycling over Antarctica during the middle Miocene warming. Nature Geoscience 5: 557-560. doi: 10.1038/ngeo1498 
Flower BP, Kennett JP (1995) Middle Miocene deepwater paleoceanography in the southwest Pacific: relations with East Antarctic ice sheet development. Paleooceanography 10(6): 1095-1112.

Francis JE, Hill RS (1996) Fossil plants from the Pliocene Sirius Group, Transantarctic Mountains: evidence for climate from growth rings and fossil leaves. Palaios 11(4): 389-396. doi: $10.2307 / 3515248$

Hill RS, Harwood DM, Webb P-N (1996) Nothofagus beardmorensis (Nothofagaceae), a new species based on leaves from the Pliocene Sirius Group, Transantarctic Mountains, Antarctica. Review of Palaeobotany and Palynology 94(1-2): 11-24. doi: 10.1016/S0034-6667(96)00003-6

Jeannel R (1927) Monographie des Trechinae. Morphologie comparée et distribution géographique d'un groupe de Coléoptères (2em livr). L'Abeille Journal d'Entomologie 33: $1-592$.

Jeannel R (1962) Les Trechides de la paléantarctide occidentale. Biologie de L'Amerique Australe 1: 527-655. [Deboutteville CD, Rapaport E]

Lewis AR, Ashworth AC (2016) An early to middle Miocene record of ice-sheet and landscape evolution from the Friis Hills, Antarctica. Geological Society of America Bulletin 128(5-6): 719-738. doi: 10.1130/B31319.1

Lewis AR, Marchant DR, Ashworth AC, Hedenäs L, Hemming SR, Johnson JV, Leng ML, Machlus ML, Newton AE, Raine JI, Willenbring JK, Williams M, Wolfe AP (2008) MidMiocene cooling and the extinction of tundra in continental Antarctica. PNAS 105(31): 10676-10680. doi: 10.1073/pnas.0802501105

Lorenz W (2005) Systematic list of extant ground beetles of the world (Insecta, Coleoptera "Geadephaga": Trachypachidae and Carabidae incl. Paussinae, Cicinidelinae, Rhysodinae). Privately published, W. Lorenz, Tutzing, 530 pp.

Mercer JH (1972) Some observations on the glacial geology of the Beardmore Glacier area. In: Adie RJ (Ed.) Antarctic Geology and Geophysics, International Union of Geological Sciences Series B -Number 1. Universitetsforlaget, Oslo, 427-433.

Mahaney WC, Hart KM, O’Reilly SS, Allen CCR, Dohm JM, Hancock RGV, Kelleher BP, Milne MW (2012) Coleoptera and microbe biomass in Antarctic Dry Valley paleosols adjacent to the Inland Ice: Implications for Mars. Planetary and Space Science 60(1): 386-389. doi: 10.1016/j.pss.2011.11.008

McKelvey BC, Webb P-N, Harwood DM, Mabin MCG (1991) The Dominion Range Sirius Group: A record of the late Pliocene-early Pleistocene Beardmore Glacier. In: Thomson MRA, Crame JA, Thomson JW (Eds) Geological evolution of Antarctica. Cambridge University Press, Cambridge, 675-682.

Mildenhall DC, Mortimer N, Bassett KN, Kennedy EM (2014) Oligocene paleogeography of New Zealand: maximum marine transgression. New Zealand Journal of Geology and Geophysics 57(2): 107-109. doi: 10.1080/00288306.2014.904587

Moore BP (1972) A revision of the Australian Trechinae (Coleoptera: Carabidae). Australian Journal of Zoology, Supplement No. 18: 1-61.

Motschulsky V de (1862a) Entomologie speciale. Remarques sur al collection d'insectes de V. de Motschulsky. Coléoptères. Études Entomologiques 11: 15-55. 
Scherer RP, DeConto RM, Pollard D, Alley RB (2016) Windblown Pliocene diatoms and East Antarctic Ice Sheet retreat. Nature Communications 12957. doi: 10.1038/ncomms12957 Warny S, Askin RA, Hannah MJ, Moh BAR, Raine JI, Harwood DM, Florindo F, SMS Science Team (2009) Palynomorphs from a sediment core reveal a sudden remarkably warm Antarctica during the middle Miocene. Geology 37(10): 955-958. doi: 10.1130/ G30139A

Webb P-N, Harwood DM (1987) Late Neogene terrestrial flora of Antarctica. Its significance in interpreting Late Cenozoic glacial history. Antarctic Journal of the United States 22: $7-11$.

Webb P-N, Harwood DM, Mabin MGC, McKelvey BC (1994) Late Neogene uplift of the Transantarctic Mountains in the Beardmore Glacier region. Terra Antarctica 1(2): 463-467.

Webb P-N, Harwood DM, Mabin MGC, McKelvey BC (1996) A marine and terrestrial Sirius group succession, middle Beardmore glacier Queen Alexandra range, Transantarctic mountains, Antarctica. Marine Micropaleontology 27(1-4): 273-297. doi: 10.1016/03778398(95)00066-6

Wei LJ, Raine JI, Liu XH (2013) Terrestrial palynomorphs of the Cenozoic Pagodroma Group, northern Prince Charles Mountains, East Antarctica. Antarctic Science 26(1): 69-70. doi: $10.1017 /$ S0954102013000278 